\title{
Effect of compost and chemical fertilizer addition on improving calcareous soil properties in Ras sudr area
}

\author{
Hoda A. Elia \\ Desert Research Center, El-Matariya, Cairo,Egypt.E-mail: h.a.elia@hotmai.com
}

Diia S.M. Boulos

Desert Research Center, El-Matariya, Cairo,Egypt.E-mail:dialsd@yahoo.com

\author{
Received: 18 Sept. 2019 / Accepted 05 Nov. 2019 / Publication date: 10 Nov. 2019
}

\begin{abstract}
Field experiment was carried out on a calcareous loamy sand soil at Ras Sudr Station, South Sinai Governorate, during two season successive in winter season of 2017/2018 cultivated by fennel plant (Foeniculum vulgare Mill.) and in summer season 2018 cultivated by pearl millet (Pennisetum glaucum L.). The current work aims to asses effect of compost application as organic amendment at rates of $0,5,10$, and 15 ton. $^{-1} \mathrm{ed}^{-1}$, recommended chemical fertilizer of each plant and their combination on soil physical and chemical properties and its productivity. A complete randomize plot design used with three replications of treatments under studied. The results showed that, application of compost and combination treatments (compost + recommended chemical fertilizer) were significantly decreased effected soil bulk density, hydraulic conductivity, EC, $\mathrm{pH}$ and SAR values after each of the first and the second seasons comparing to control. On contrary in case of the recommended chemical fertilizer did not affect of these parameters. Meanwhile soil available water, available $\mathrm{N}, \mathrm{P}$ and $\mathrm{K}$ after each of the first and the second seasons and productivity of fennel plant and pearl millet respectively, were significantly increased. In addition, the results showed that, the affect of difference significantly of treatments under studied after the first season higher than after the second season on soil properties.
\end{abstract}

Keywords: soil compost, recommended chemical fertilizer, physical and chemical properties.

\section{Introduction}

Calcareous soils are ones in Egypt. The main problems of these soils are related to one or more of the following: high salinity, high $\mathrm{pH}$, lack of adequate texture and structure, very poor in organic matter or biological activities, distractive effect of some macro and micro-nutrients availability. Abd El-Moez et al. (2002) found that, application of composted materials to the saline calcareous soil decreased both EC and pH values. Abd El-Moez and Saleh, (1999) found that the organic materials have a different effect in modifications of the properties of soil as well as their influence on their nutrition status and soil fertility. Gilley and Risse, (2000) mentioned that long-term annual compost and manure treatments caused to improved structure.

Compost is friendly to the environmental means because it does to reduce the waste going to soil. Also the production of compost is considered an economic. Treated soil by compost can improve its physical and chemical properties, in addition the productivity as well as agricultural production was sustainability by replenishing soil organic matter and supplying nutrients. Compost is the best component of a good healthy soil, this due to the compost plays an important role in soil physical, chemical and biological properties. The volume of the organic matter reduction during composting and the resulting compost is nutrient rich and more stable than the organic matter (feedstock) and can improvement of soil properties and its productivity. (Barral et al., 2009; Farrell and Jones, 2009). The cost of chemical fertilizers and the potential environmental risk posed by overuse have renewed the interest in using amendments such as plant residues, manures. According to De Bertoldi et al. (1983) and Bernal et al. (2009) composts have several advantages compared to plant residues when applied to soils, such as reduced volume, slower mineralization rates and recycling of municipal bio-solid wastes. Compost has two main effects on soils, particularly nutrient poor soils: replenish organic residual in soil and supply plant nutrients (Tejada et al., 2009). Organic matter plays a crucial role ameliorative physical, chemical and biological properties of soils.

Soil structure can be improved by the binding between soil compost and clay particles via cation bridges and through stimulation of biological activity and root growth (Gao et al., 2010). Effect

Corresponding Author: Hoda A. Elia, Desert Research Center, El-Matariya, Cairo, Egypt. 
of compost include increasing water field capacity and plant water availability Farrell and Jones (2009), decreasing leaching of nutrients (Hepperly et al., 2009). Most main macro and micro-nutrients in compost are in organic forms which are released slowly and are less subject to leaching relatively to chemical fertilizers (Larney et al., 2008). The incorporation of compost derived from biogenic household and garden waste to soils increases soil carbon and total $\mathrm{N}$ concentrations (Mylavarapu and Zinati, 2009). Application of compost to soil has been shown to limit water loss via evaporation, increase soil organic material and thus water retention and availability (Weber et al., 2002). Celik et al. (2004) reported that the effect of addition compost in soil on the water availability increased by $58-86 \%$ as a result of increase in macro and micro porosity. Applying compost to soils can increase plant nutrient availability (Kawasaki et al., 2008). Compared to the same amount of $\mathrm{N}$ and $\mathrm{P}$ added, plant $\mathrm{N}$ and $\mathrm{P}$ uptake from compost may be lower than that from inorganic $\mathrm{N}$ fertilizer, because the organic $\mathrm{N}$ in the compost has to be mineralized before it can be adsorbed by plants or because of microbial immobilization of N (Odlare and Pell, 2009).

\section{Materials and Methods}

Field experiment was carried out during two successive seasons (winter 2017/2018 and summer 2018) in Ras Sudr station South Sinai, calcareous loamy sand soil texture, to study the effect of application different rates of compost, recommended chemical fertilizer and their combination on some soil physical and chemical properties. The experimental treatments were control, Recommended chemical fertilizer, compost $\left(5,10\right.$ and 15 ton.fed $\left.{ }^{-1}\right)$, compost 5 ton.fed ${ }^{-1}+$ recommended chemical fertilizer, compost 10 ton.fed ${ }^{-1}+$ recommended chemical fertilizer and compost 15 ton.fed ${ }^{-1}+$ recommended chemical fertilizer. In the first season, fennel plant (Foeniculum vulgare Mill.) was planted in November 2017/2018. The recommended chemical fertilizer were $300 \mathrm{~kg} / \mathrm{fed}$ calcium super phosphate during land preparation, while $300 \mathrm{~kg} / \mathrm{fed}$ ammonium sulphate and $100 \mathrm{~kg} / \mathrm{fed}$ potassium sulphate were added during growth season. While in the second season, pearl millet (Pennisetum glaucum L.) cultivated in July 2018. The recommended chemical fertilizer were $45 \mathrm{~kg}$ $\mathrm{P}_{2} \mathrm{O}_{5} \mathrm{fed}^{-1}$ as super phosphate before cultivation, $80 \mathrm{~kg} \mathrm{~N} f e d^{-1}$, as $\mathrm{NH}_{4} \mathrm{NO}_{3}$ and $60 \mathrm{~kg} \mathrm{~K}_{2} \mathrm{O}$ fed ${ }^{-1}$, as $\mathrm{K}_{2} \mathrm{SO}_{4}$. In the winter season, the plots treated by compost were added only once before planting and mixing in $15 \mathrm{~cm}$ soil depth. This experiment was under the drip irrigation system. The EC and SAR (Sodium Adsorbed Ratio) for irrigation water were, $8.96 \mathrm{dSm}^{-1}$ and 22.74, respectively.

Compost was prepared at the Ras Sudr Station, using different organic materials like barley residues, leaves and soft parts of different trees, sheep dung and chicken manure, added $2.5 \mathrm{~kg}$ $\mathrm{NH}_{4} \mathrm{NO}_{3}, 5 \mathrm{~kg}$ super phosphate and $2.5 \mathrm{~kg} \mathrm{~K}_{2} \mathrm{SO}_{4} / \mathrm{m}^{3}$ compost as a source of mineral fertilizers. The mixture were composted for three months before adding to the plots.

At the end of the growing each season, the fennel ( $\left.\mathrm{kg} \cdot \mathrm{fed}^{-1}\right)$ and pearl millet (ton.fed ${ }^{-1}$ ) productivity were recorded. The soil samples were collected from the upper soil surface layer of each treated plots in the end of the first and the second seasons, for the physical and chemical analyses, which were determined using the standard methods given by Klute (1986) and Jackson (1973). Data of soil analyses are tabulated in Table (1).

Table 1: Analysis data of the initial soil of Ras Sudr and compost

\begin{tabular}{|c|c|c|c|}
\hline \multicolumn{2}{|c|}{ Analysis of the initial soil } & \multicolumn{2}{|c|}{ Analysis of compost } \\
\hline Coarse sand \% & 23.56 & EC dS. $m^{-1}$ & 4.24 \\
\hline Fine sand $\%$ & 54.86 & pH & 7.11 \\
\hline Silt \% & 12.45 & Organic matter \% & 61.32 \\
\hline Clay \% & 9.13 & Total Carbon \% & 8.97 \\
\hline Textural class & Loamy sand & C:N ratio & 14.5 \\
\hline Bulk density Ma.m ${ }^{-3}$ & 1.51 & Available $\mathbf{N}$ gm. $\mathrm{Kg}^{-1}$ & 6.218 \\
\hline Particle density Mg. $\mathrm{m}^{-3}$ & 2.61 & Available $\mathbf{P}$ gm.Kg $\mathbf{g}^{-1}$ & 5.133 \\
\hline Total porosity \% & 42.15 & Available $\mathrm{K}{\mathrm{gm} . \mathrm{Kg}^{-1}}^{-1}$ & 5.992 \\
\hline $\mathrm{CaCO}_{3} \%$ & 50.12 & & \\
\hline Organic matter \% & 0.42 & & \\
\hline Field capacity & 12.63 & & \\
\hline Welting point & 4.18 & & \\
\hline Available water & 8.45 & & \\
\hline Hydraulic conductivity $\mathrm{cm}^{-\mathrm{h}^{-1}}$ & 7.32 & & \\
\hline
\end{tabular}


The experimental is a complete randomize plot design with three replicates. Statistical analysis of variance of all studied treatments was ANOVA and the least significant difference (L.S.D) at 0.05 $\%$ level.

\section{Results and Discussion}

\section{Soil bulk density (BD)}

Results in Table (2) reveal that all treatments application seemed to be highly effective relative on soil bulk density $\left(\mathrm{Mg} . \mathrm{m}^{-3}\right)$ except the recommended chemical fertilizer treatment. The application of compost 5, 10 and 15 ton.fed ${ }^{-1}$ lead to, soil BD $\left(\mathrm{Mg} . \mathrm{m}^{-3}\right)$ values decreased by $1.46,1.37$ and 1.26 $\mathrm{Mg} \cdot \mathrm{m}^{-3}$. In addition, BD values decreased to $1.47,1.39$ and $1.28 \mathrm{Mg} \cdot \mathrm{m}^{-3}$ by the application of compost

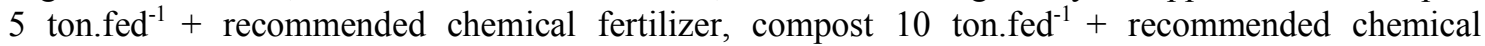
fertilizer and compost 15 ton. fed $^{-1}+$ recommended chemical fertilizer, as compared with control, respectively. Also data showed clearly that recommended chemical fertilizer had no significantly effect on soil bulk density. On the other hand, the compost and combinations between compost and recommended chemical fertilizer had significantly decreased of the soil bulk density relative to control. These results can be attributed to the redistribution of soil particles, the increase in bulk soil volume and the binding action of compost which assess to improve soil structure, mainly in aggregate formation. In addition, compost treatments reduced the BD of soil to its least, as it promotes total porosity because bacterial glue acts as soil particle binding agent. These binding agents decrease the bulk density of the soil by improving soil aggregation and increasing porosity. Moreover, the reduction in $\mathrm{BD}$ may be related to the mixing of soil with less dense organic material or by enhancing the fine particle aggregation, leading to the higher pore volume in the soil as well as a decreased particle density. Thus increase in compost caused a relatively larger decrease in soil bulk densities. These findings are very close to that obtained by Omran et al. (2002).

Table 2: Effect of different treatments on some soil physical.

\begin{tabular}{|c|c|c|c|c|c|c|}
\hline \multirow[b]{2}{*}{ Treatment } & \multicolumn{3}{|c|}{ After first season (fennel) } & \multicolumn{3}{|c|}{$\begin{array}{l}\text { After second season (pearl } \\
\text { millet) }\end{array}$} \\
\hline & $\underset{\left(\mathbf{M g}^{\text {B. }}{ }^{-3}\right)}{\text { BD }}$ & $\begin{array}{l}\text { AW } \\
(\%)\end{array}$ & $\underset{\left(\mathbf{c m} \cdot h^{-1}\right)}{\mathbf{H C}}$ & $\begin{array}{c}\text { BD } \\
\left(\mathbf{M g}^{-3} \mathbf{m}^{-3}\right)\end{array}$ & $\begin{array}{l}\text { AW } \\
(\%)\end{array}$ & $\begin{array}{c}\mathbf{H C} \\
\left(\mathrm{cm}^{-1} \mathbf{h}^{-1}\right)\end{array}$ \\
\hline Control & $1.51 \mathrm{a}$ & $8.89 \mathrm{c}$ & $8.06 \mathrm{a}$ & $1.51 \mathrm{~b}$ & $8.45 \mathrm{~b}$ & $8.19 \mathrm{a}$ \\
\hline Recommended chemical fertilizer & $1.52 \mathrm{a}$ & $8.92 \mathrm{c}$ & $8.21 \mathrm{a}$ & $1.54 \mathrm{a}$ & $8.67 \mathrm{~b}$ & $8.21 \mathrm{a}$ \\
\hline Compost 5 ton.fed ${ }^{-1}$ & $1.46 \mathrm{~b}$ & $13.65 \mathrm{~b}$ & $6.58 \mathrm{ab}$ & $1.48 \mathrm{bc}$ & $10.05 \mathrm{ab}$ & $7.67 \mathrm{ab}$ \\
\hline Compost 10 ton. fed $^{-1}$ & $1.37 \mathrm{c}$ & $16.78 \mathrm{a}$ & $5.43 \mathrm{~b}$ & $1.42 \mathrm{~d}$ & $10.63 \mathrm{ab}$ & $7.11 \mathrm{ab}$ \\
\hline Compost 15 ton. fed $^{-1}$ & $1.26 \mathrm{~d}$ & $17.46 \mathrm{a}$ & $4.79 \mathrm{~b}$ & $1.39 \mathrm{~d}$ & $12.08 \mathrm{a}$ & $6.92 \mathrm{ab}$ \\
\hline Compost 5 ton. fed $^{-1}+$ fertilizer & $1.47 \mathrm{ab}$ & $14.05 \mathrm{~b}$ & $5.87 \mathrm{~b}$ & $1.48 \mathrm{bc}$ & $10.31 \mathrm{ab}$ & $6.82 \mathrm{ab}$ \\
\hline Compost 10 ton. fed $^{-1}+$ fertilizer & $1.39 \mathrm{c}$ & $16.52 \mathrm{a}$ & $5.76 \mathrm{~b}$ & $1.43 \mathrm{~cd}$ & $11.26 \mathrm{ab}$ & $6.46 \mathrm{ab}$ \\
\hline Compost 15 ton.fed $^{-1}+$ fertilizer & $1.28 \mathrm{~d}$ & $17.89 \mathrm{a}$ & $4.82 \mathrm{~b}$ & $1.38 \mathrm{~d}$ & $12.54 \mathrm{a}$ & $6.30 \mathrm{~b}$ \\
\hline Significant & $* * *$ & $* * *$ & $* *$ & $* *$ & $*$ & $*$ \\
\hline $\mathrm{LSD}_{, 0.05}$ & 0.06 & 2.13 & 1.57 & 0.04 & 1.96 & 1.2 \\
\hline
\end{tabular}

\section{Soil available water}

The influenced of compost and recommended chemical fertilizer as well as their combinations on the soil available water, has been given in Table (2) and Fig. (1). It is evident that, soil available water increased with increasing rates of compost and compost + recommended chemical fertilizer. Soil available water was increased by 34.87 and $15.92 \%$ with compost 5 ton.fed ${ }^{-1}, 47.02$ and $20.51 \%$ with compost 10 ton.fed ${ }^{-1}, 49.08$ and $30.05 \%$ with compost 15 ton.fed ${ }^{-1}, 36.73$ and $18.04 \%$ with compost 5 ton.fed ${ }^{-1}+$ recommended chemical fertilizer, 46.19 and $24.96 \%$ with compost 10 ton.fed $^{-1}$ + recommended chemical fertilizer and 50.31 and $32.62 \%$ with compost 15 ton.fed ${ }^{-1}+$ recommended chemical fertilizer after the first and the second seasons relatively to control, respectively. In addition, results in Table (2) clearly indicated that add of recommended chemical fertilizer have no significant affected on soil available water. In the same trend, no significant affect among between compost and / or compost + recommended chemical fertilizer. In reverse, data reveal that soil available water as affected by different treatments rates and integrated application of compost and recommended 
chemical fertilizer was significant variations. This may be due to adding the compost to soil and hence increases the amount of available water in soil. The findings of this study were in agreement with the findings of Candemir and Gülser (2011); Cercioglu et al. (2012) they found that the addition of organic wastes into soils reduces bulk density and increases soil available water.

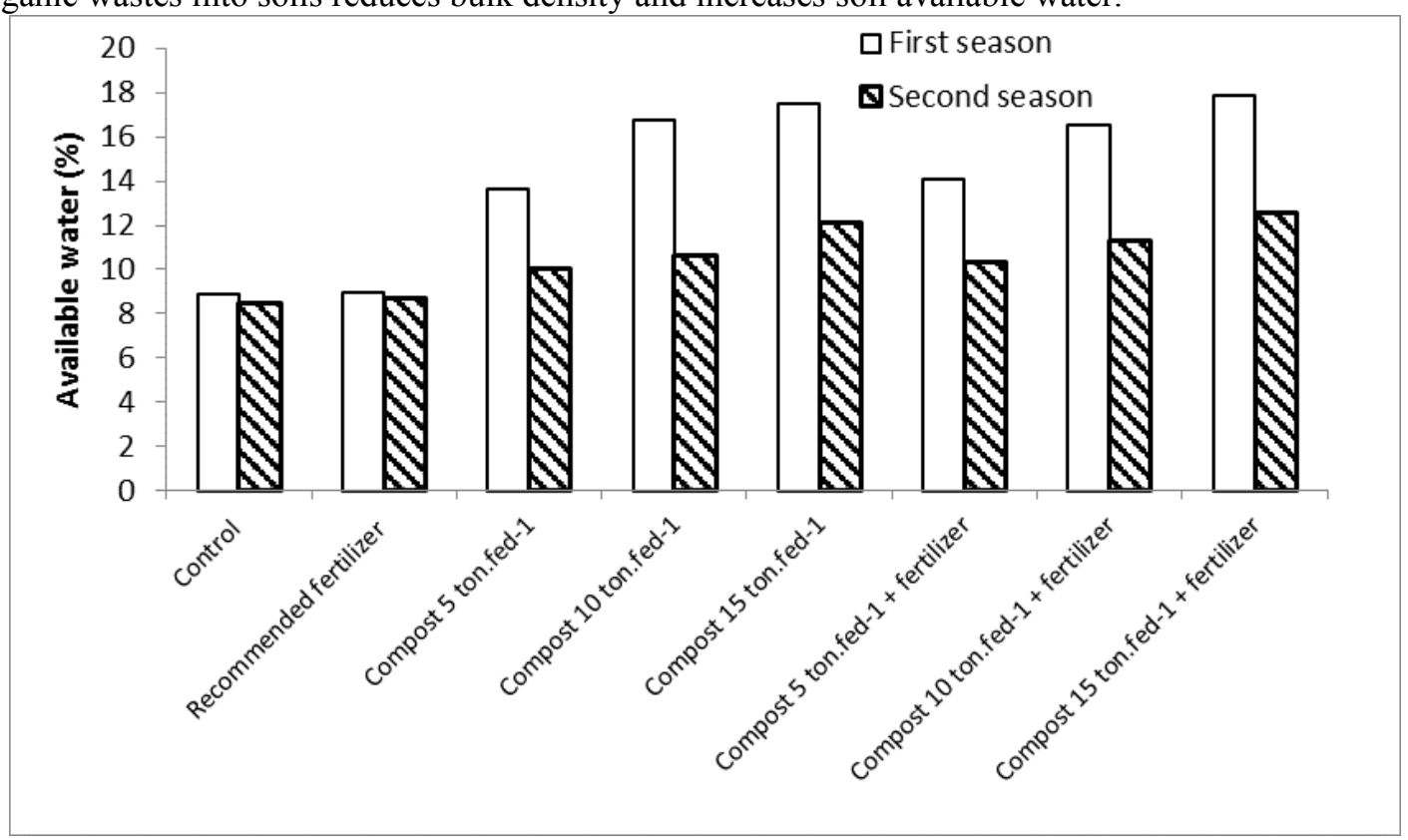

Fig. 1: Effect of different treatments on available water (\%).

\section{Saturated hydraulic conductivity}

The effect of different compost and recommended chemical fertilizer as well as their combinations on soil hydraulic conductivity (HC), are shown in Table (2) and Fig. (2). Data showed clearly that, the hydraulic conductivity $\left(\mathrm{cm} \cdot \mathrm{h}^{-1}\right)$ values were significantly decreased with the increasing rates of compost and combination treatments (compost + recommended chemical fertilizer) relatively to control. In reverse the recommended chemical fertilizer treatment had no significant effect on soil hydraulic conductivity. Also it was observed that the lowest value of hydraulic conductivity was $4.79 \mathrm{~cm} \cdot \mathrm{h}^{-1}$ at compost 15 ton. $\mathrm{fed}^{-1}$. Meanwhile, the highest value of hydraulic conductivity was $8.21 \mathrm{~cm} \cdot \mathrm{h}^{-1}$ at recommended chemical fertilizer treatment.

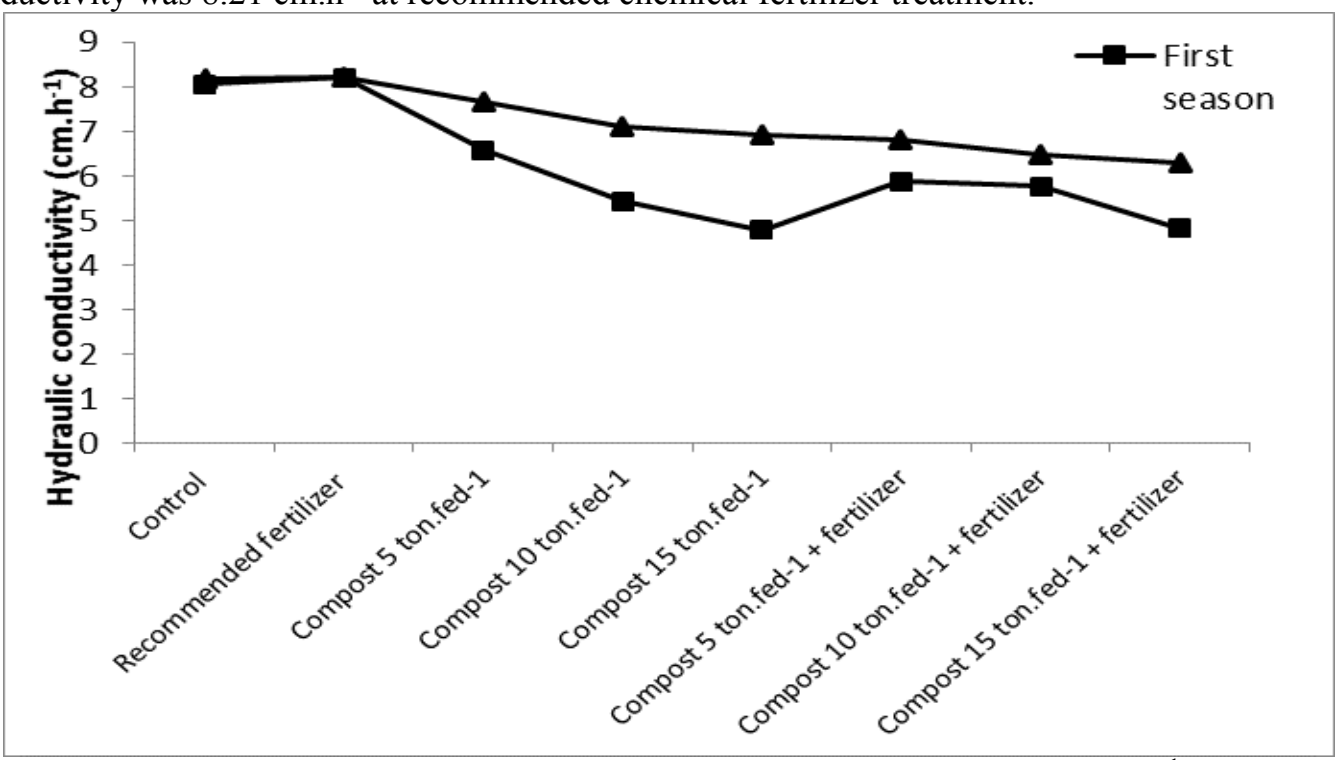

Fig. 2: Effect of different treatments on hydraulic conductivity $\left(\mathrm{cm} \cdot \mathrm{h}^{-1}\right)$. 


\section{Soil electrical conductivity and sodium adsorption ratio:}

The effect of different rates of compost (as organic amendments), recommended chemical fertilizer and their combination on soil salinity. Data in Table (3) show that the soil EC (dS.m $\left.{ }^{-1}\right)$ values decreased as a result of the different treatments in two seasons. The highest reduction of EC values, which was in the soil treated with different soil treatments in the first and the second seasons, decrements were arranged as follow: compost 15 ton.fed ${ }^{-1}>$ compost 15 ton.fed ${ }^{-1}+$ recommended fertilizer $>$ compost 10 ton. fed $^{-1}>$ compost 10 ton. fed $^{-1}+$ recommended fertilizer $>$ compost 5 ton.fed $^{-}$ ${ }^{1}>$ compost 5 ton.fed ${ }^{-1}+$ recommended fertilizer $>$ recommended chemical fertilizer $>$ control. Where, in the first season the change rates in soil EC were 22.31, 20.8, 18.53, 17.89, 15.52, 11.96, and 2.48\% relatively to control. Meanwhile, in the second season the change rates of the EC were 20.09, 18.55, $15.48,14.16,9,8.01$ and $2.52 \%$ relatively to control.

In the first and the second season, the reduction of soil EC resulted from the addition of different treatments were highly significant relative to control except recommended chemical fertilizer. However, EC was insignificantly within compost 5 ton. fed $^{-1}$ and compost 10 ton. fed $^{-1}$ also compost 10 ton.fed ${ }^{-1}+$ recommended chemical fertilizer and compost 15 ton.fed ${ }^{-1}+$ recommended chemical fertilizer In reversely data shown that no significant among different rates of compost and their combine with recommended chemical fertilizer. These results are in agreement with Ashour, (2014) and El-Maaz et al., (2014) they revealed that the application of compost led to decrease of EC soil.

Application of compost, chemical fertilizer and their combination at different levels reduced sodium adsorption ratio (SAR) of soil after the first and the second seasons significantly as compared to control as well as chemical fertilizer Table (3). The highest values 8.91 and 8.76 of SAR were recorded in control respectively, after the first and the second seasons. In addition the lowest values were 7.34 and 7.36 of compost 5 ton.fed ${ }^{-1}$ and compost 5 ton.fed $^{-1}+$ recommended chemical fertilizer, respectively. Studies of Zaka et al., (2003) also indicated that, the same trend of decrease in soil SAR with use of FYM, rice straw and Sesbania green manure. They attributed that, the reduction in SAR of the soil with organic materials due to the release of organic acids causing mobilization of native calcium present as $\mathrm{CaCO}_{3}$ in the soil. The values of SAR become lesser either due to an increase in divalent cations $(\mathrm{Ca}+\mathrm{Mg})$ or decrease in mono-valent cation $(\mathrm{Na})$. Values of $\mathrm{Na}$ could decrease during leaching while $\mathrm{Ca}+\mathrm{Mg}$ increase due to reactions of organic acids with $\mathrm{CaCO}_{3}$ after the application of compost. The chemical reactions proposed under soil $\mathrm{pH}$ section above further elaborates how a net increase in $\mathrm{Ca}+\mathrm{Mg}$ and decrease in $\mathrm{Na}$ in the soil solution occurred. The acid or acid forming substances expelled $\mathrm{Na}$ or $\mathrm{Ca}+\mathrm{Mg}$ from the clay micelle, the hydrogen ion taking their place. Sodium salts being readily water soluble left the soil system and went into the lower depths of soil profile. The divalent cations $(\mathrm{Ca}+\mathrm{Mg})$ increased the net concentration of the soil solution. However, a part of these would have also precipitated with carbonates $\left(\mathrm{CO}_{3}\right)$ and bicarbonates $\left(\mathrm{HCO}_{3}\right)$ present in the soil. The released $\mathrm{Ca}$ increased the $\mathrm{Ca}$ concentration of the soil solution resulting in decrease of soil SAR .

Table 3: Effect of different treatments on some soil chemical properties.

\begin{tabular}{|c|c|c|c|c|c|c|}
\hline \multirow{2}{*}{ Treatment } & \multicolumn{3}{|c|}{ After fennel } & \multicolumn{3}{|c|}{ After pearl millet } \\
\hline & $\mathrm{EC}\left(\mathrm{dS} . \mathrm{m}^{-1}\right)$ & $\mathbf{p H}$ & SAR & $\mathrm{EC}\left(\mathrm{dS} . \mathrm{m}^{-1}\right)$ & $\mathbf{p H}$ & SAR \\
\hline Control & $9.28 \mathrm{a}$ & $7.84 \mathrm{a}$ & $8.91 \mathrm{a}$ & $9.19 \mathrm{a}$ & $7.81 \mathrm{a}$ & $8.76 \mathrm{a}$ \\
\hline Recommended chemical fertilizer & $9.05 \mathrm{a}$ & $7.71 \mathrm{~b}$ & $8.95 \mathrm{a}$ & $8.88 \mathrm{a}$ & $7.78 \mathrm{a}$ & $8.26 \mathrm{~b}$ \\
\hline Compost 5 ton. fed $^{-1}$ & $8.17 \mathrm{~b}$ & $7.48 \mathrm{c}$ & $8.26 \mathrm{~b}$ & $8.31 \mathrm{~b}$ & $7.64 \mathrm{~b}$ & $8.21 \mathrm{~b}$ \\
\hline Compost 10 ton. fed $^{-1}$ & $7.84 \mathrm{bc}$ & $7.41 \mathrm{c}$ & $7.59 \mathrm{c}$ & $8.29 \mathrm{~b}$ & $7.51 \mathrm{bc}$ & $7.83 \mathrm{c}$ \\
\hline Compost 15 ton. fed $^{-1}$ & $7.62 \mathrm{bc}$ & $7.41 \mathrm{c}$ & $7.34 \mathrm{c}$ & $7.82 \mathrm{bc}$ & $7.51 \mathrm{bc}$ & $7.49 \mathrm{~d}$ \\
\hline Compost 5 ton. fed $^{-1}+$ fertilizer & $7.56 \mathrm{bc}$ & $7.39 \mathrm{c}$ & $8.38 \mathrm{~b}$ & $7.70 \mathrm{bc}$ & $7.58 \mathrm{bc}$ & $7.36 \mathrm{e}$ \\
\hline Compost 10 ton. fed $^{-1}+$ fertilizer & $7.35 \mathrm{bc}$ & $7.38 \mathrm{c}$ & $7.76 \mathrm{c}$ & $7.42 \mathrm{c}$ & $7.55 \mathrm{bc}$ & $7.88 \mathrm{c}$ \\
\hline Compost 15 ton.fed $^{-1}+$ fertilizer & $7.21 \mathrm{c}$ & $7.36 \mathrm{c}$ & $7.41 \mathrm{c}$ & $7.28 \mathrm{c}$ & $7.45 \mathrm{c}$ & $7.56 \mathrm{~d}$ \\
\hline Significant & $* * *$ & $* *$ & $* * *$ & $* *$ & $* *$ & $* *$ \\
\hline $\mathrm{LSD}_{, 0.05}$ & 0.65 & 0.13 & 0.4 & 0.54 & 0.10 & 0.15 \\
\hline
\end{tabular}




\section{Soil pH:}

Application of compost to the investigated soil had a negative significant effect on soil $\mathrm{pH}$. In the first and the second season, the added different treatments to the soil were highly significant decreased on the soil $\mathrm{pH}$ relative to control except recommended chemical fertilizer in the second season. In contrast that, in case of different treatments of compost, it was no significant effect on soil $\mathrm{pH}$. Table (3) the $\mathrm{pH}$ of the compost treated soils decreased with increasing the rates of soil compost and combine compost + recommended chemical fertilizer, but slightly decrease with alone recommended chemical fertilizer. In the first and the second seasons, the highest values 7.84 and 7.81 of the soil $\mathrm{pH}$ were observed for the soil control. The lowest values 7.36 and 7.45 of the soil $\mathrm{pH}$ were found for the soil treated with compost 15 ton. fed $^{-1}+$ recommended chemical fertilizer, respectively.

These decreases in soil $\mathrm{pH}$ induced by the addition of compost treatments can be attributed to the acidic effect of decomposable products of organic materials. Soil $\mathrm{pH}$ can be decrease after application of compost from rice straw mixed with agro-industrial wastes due to the release of $\mathrm{H}^{+}$via nitrification and/or the production of organic acids during decomposition (Rashad et al. 2011). Also, addition of compost from manure has been reported to both increase and decrease soil $\mathrm{pH}$ and have the ability to buffer soil $\mathrm{pH}$ (Johnson et al. 2006).

\section{Macronutrient contents (N, $P$ and $K)$ :}

Data presented in Table (4) show the soil content $\left(\mathrm{mg} \mathrm{kg}^{-1}\right)$ of available macronutrients $(\mathrm{N}, \mathrm{P}$ and $\mathrm{K}$ ) as affected by compost (as organic amendments), recommended chemical fertilizer and their combination. The effect of all treatments rates on $\mathrm{N}, \mathrm{P}$ and $\mathrm{K}$ content in soil were high significantly increase, This may be attributed to $\mathrm{pH}$ decreased as a result of adding compost to the soil, which is responsible for nutrients availability in soils. El-Maaz et al. (2014) found that the general increase in nutrient supplying capacity of soils with addition of compost. These results are in agreement with those of Abd El-Mouty et al. (2001), Awad (2002) and EL-Etr et al. (2004).

All treatments compost or / and compost + recommended chemical fertilizer were effected on available Nitrogen, Phosphors and Potassium in calcareous soil. Organic materials mineralization released from compost or compost + recommended chemical fertilizer are answerable of increase the nutrients availability in soil.

Table 4: Effect of different treatments on available N, P and K.

\begin{tabular}{|c|c|c|c|c|c|c|}
\hline \multirow{3}{*}{ Treatment } & \multicolumn{3}{|c|}{ After first season (fennel) } & \multicolumn{3}{|c|}{ Ifter second season (pearl millet) } \\
\hline & \multicolumn{6}{|c|}{$\mathrm{mg} / \mathrm{kg}$ soil } \\
\hline & $\mathbf{N}$ & $\mathbf{P}$ & $\mathbf{K}$ & $\mathbf{N}$ & $\mathbf{P}$ & $\mathbf{K}$ \\
\hline Control & $38 \mathrm{f}$ & $2.60 \mathrm{e}$ & $96.12 \mathrm{~h}$ & $38 \mathrm{f}$ & $2.60 \mathrm{e}$ & $89 \mathrm{~g}$ \\
\hline Recommended chemical fertilizer & $93 \mathrm{e}$ & $3.92 \mathrm{~d}$ & $127.18 \mathrm{~g}$ & $87 \mathrm{e}$ & $3.20 \mathrm{~d}$ & $108 \mathrm{f}$ \\
\hline Compost 5 ton.fed ${ }^{-1}$ & $111 \mathrm{~d}$ & $5.52 \mathrm{c}$ & $198.46 \mathrm{f}$ & $105 \mathrm{~d}$ & $4.90 \mathrm{c}$ & $158 \mathrm{e}$ \\
\hline Compost 10 ton. fed ${ }^{-1}$ & $141 \mathrm{c}$ & $6.12 \mathrm{bc}$ & $214.66 \mathrm{e}$ & $135 \mathrm{c}$ & $5.50 \mathrm{bc}$ & $193 \mathrm{~d}$ \\
\hline Compost 15 ton. fed $\mathrm{d}^{-1}$ & $173 \mathrm{~b}$ & $6.92 \mathrm{~b}$ & $274.06 \mathrm{~b}$ & $167 \mathrm{~b}$ & $6.30 \mathrm{~b}$ & $231 \mathrm{~b}$ \\
\hline Compost 5 ton. fed $^{-1}+$ fertilizer & $135 \mathrm{c}$ & $6.42 \mathrm{bc}$ & $240.58 \mathrm{~d}$ & $129 \mathrm{c}$ & $5.70 \mathrm{bc}$ & $198 \mathrm{~d}$ \\
\hline Compost 10 ton. fed $^{-1}+$ fertilizer & $164 \mathrm{~b}$ & $7.02 \mathrm{~b}$ & $250.30 \mathrm{c}$ & $158 \mathrm{~b}$ & $6.40 \mathrm{~b}$ & $214 \mathrm{c}$ \\
\hline Compost 15 ton.fed f $^{-1}+$ fertilizer & $222 \mathrm{a}$ & $7.97 \mathrm{a}$ & $326.98 \mathrm{a}$ & $216 \mathrm{a}$ & $7.35 \mathrm{a}$ & $298 \mathrm{a}$ \\
\hline Significant & $* * *$ & $* * *$ & $* * *$ & $* *$ & $* *$ & $* *$ \\
\hline $\mathrm{LSD}_{, 0.05}$ & 13.78 & 0.79 & 9.85 & 11.53 & 0.62 & 7.11 \\
\hline
\end{tabular}

The presented data in Table (4) also showed that, the contents $\left(\mathrm{mg} \mathrm{kg}^{-1}\right)$ of available phosphorus in calcareous soil were greatly affected by the studied treatments, where it increased with the increase in the application rates of compost (as organic amendments), recommended chemical fertilizer and their combination. These increases of available phosphorus contents in soil after the first season were greater than those in soil after the second season. The obtained increases in calcareous soil content of available $\mathrm{P}$ as a result of the treatments (compost, recommended chemical fertilizer and their combination) were resulted from the decrease of soil $\mathrm{pH}$ associated of organic acids from compost which resulted in a more available $\mathrm{P}$ in soil (Tan, 2003). Also, bicarbonate ions $\left(\mathrm{HCO}_{3}\right)$ resulted from compost decomposition are reacted with soluble $\mathrm{Ca}^{+2}$ formed $\mathrm{Ca}\left(\mathrm{HCO}_{3}\right)^{2}$ which prevent the reaction between $\mathrm{Ca}^{+2}$ and $\mathrm{P}$ (phosphate), organic anions compete with phosphorus ions on adsorption sites. Turner et al. (2005) mentioned that, added compost coat the particles of $\mathrm{CaCO}_{3}$ and preventing the reaction between $\mathrm{CaCO}_{3}$ and $\mathrm{P}$ which caused $\mathrm{P}$ precipitation and fixation in insoluble 
forms as dicalcium phosphate dehydrate $\left(\mathrm{DCP} ; \mathrm{CaHPO}_{4} \cdot 2 \mathrm{H}_{2} \mathrm{O}\right)$ or octacalcium phosphate $\left(\mathrm{OCP} ; \mathrm{Ca}_{8} \mathrm{H}_{2}\left(\mathrm{PO}_{4}\right)_{6} .5 \mathrm{H}_{2} \mathrm{O}\right)$. Also, compost can affect the solubility of insoluble phosphorus compounds in calcareous soil by its chelation capacity, similar results on calcareous soil were obtained by Tan (2003) and Wandruszka (2006).

Also, Pattanayak et al. (2001) mention that the acids forming compounds are released in the form of compost to the soil, these affect potassium availability. The effect is positive resulting in more availability of $\mathrm{K}$ to the plants. In addition, the hydrogen ions released from organic materials were exchanged with $\mathrm{K}$ on exchange site. Thus, the overall status of soil regarding availability of potassium content is improved.

\section{Effect of soil amendments on productivity:}

The added compost, recommended chemical fertilizer and their combine to the studied soil had significant effects on each of productivity in the winter season (fennel crop) and in the second season (pearl millet). The applied compost amendments varied in their effects on the productivity depending upon their type and the application level. Applying the compost amendments, recommended chemical fertilizer and their combine showed increases in the yield of fennel and pearl millet compared to the control soil. Also the productivity increased gradually by increasing the rates of soil compost treatments alone. Moreover, combine of compost + recommended chemical fertilizer recorded the highest values of fennel and pearl millet as compared to those given by compost or recommended chemical fertilizer alone.

Data in Tables (5). Showed that the weight of grains fennel Kg.fed ${ }^{-1}$ increased significantly with soil compost application. The lowest value of productivity was $644 \mathrm{Kg}$.fed $\mathrm{f}^{-1}$ of control, meanwhile the highest value was $963 \mathrm{Kg}$.fed ${ }^{-1}$ of soil compost 15 ton.fed ${ }^{-1}+$ recommended chemical fertilizer. In the second season data showed that, productivity of pearl millet ton.fed ${ }^{-1}$ increased significantly with soil compost application. The lowest value of productivity was 8.52 ton.fed $^{-1}$ of

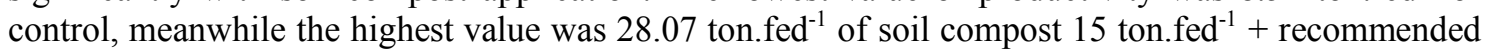
chemical fertilizer.

Table 5: Effect of different treatments on crops productivity.

\begin{tabular}{|c|c|c|}
\hline \multirow[b]{2}{*}{ Treatment } & \multicolumn{2}{|c|}{ Crops productivity } \\
\hline & $\begin{array}{c}\text { Fennel grains } \\
{\left(\mathrm{kg.fed}^{-1}\right)}^{-}\end{array}$ & $\begin{array}{l}\text { Pearl millet } \\
\text { (ton.fed }^{-1} \text { ) }\end{array}$ \\
\hline Control & $644 \mathrm{f}$ & $8.52 \mathrm{~h}$ \\
\hline Recommended chemical fertilizer & $708 \mathrm{e}$ & $11.91 \mathrm{~g}$ \\
\hline Compost 5 ton.fed ${ }^{-1}$ & 729 de & $14.28 \mathrm{f}$ \\
\hline Compost 10 ton.fed ${ }^{-1}$ & $751 \mathrm{~d}$ & $16.82 \mathrm{e}$ \\
\hline Compost 15 ton.fed ${ }^{-1}$ & $793 \mathrm{c}$ & $19.37 \mathrm{~d}$ \\
\hline Compost 5 ton. fed $^{-1}+$ fertilizer & $836 \mathrm{~b}$ & $22.71 \mathrm{c}$ \\
\hline Compost 10 ton.fed $^{-1}+$ fertilizer & $857 \mathrm{~b}$ & $25.22 \mathrm{~b}$ \\
\hline Compost 15 ton. $^{- \text {fed }^{-1}+\text { fertilizer }}$ & $963 \mathrm{a}$ & $28.07 \mathrm{a}$ \\
\hline Significant & $* * *$ & $* * *$ \\
\hline $\mathrm{LSD}_{0.05}$ & 35.56 & 0.224 \\
\hline
\end{tabular}

\section{Conclusion}

According to the results obtained, it can be concluded that, values of AW increased significantly by increasing the rate of compost combination of compost + recommended chemical fertilizer treatments were superior in increasing values of AW in both the first and the second seasons. Values of bulk density, hydraulic conductivity, EC, $\mathrm{pH}$ and SAR were decreased with increasing the rates of compost. On contrast, available of macronutrients $(\mathrm{N}, \mathrm{P}$ and $\mathrm{K})$ increased significantly with increasing the rate of compost and combination of compost + recommended chemical fertilizer treatments were superior in increasing values of macronutrients.

The superior for increasing values of each fennel and pearl millet productivity increased significantly with the application combine of compost + recommended chemical fertilizer treatment, also they increased gradually by increasing the rates combine of compost + recommended chemical fertilizer treatment. 


\section{References}

Abd El-Moez, M.R. and A.L. Saleh, 1999. Effect of organic fertilizers application on growth, yield and mineral uptake of Roselle- plants as compared to chemical fertilizer. J. Agric. Sci. Mansoura Univ. 24(6): 3157-3165.

Abd El-Moez, M.R., O. Shaleby, I.A. Abdel Latif and K.S. Abd El- Fattah, 2002. Impact of some organic residues on some properties of calcareous soil and tomato germination. Egypt J. of Soil Sci. 42, (2): 255-265.

Abd El-Mouty, M.M.; A.H. Ali and F.A. Rizk, 2001. Potato yield as affected by the interaction between bio and organic fertilizers. Egypt. J. Appl. Sci., 16 (6): 267-286.

Ashour, I.A., 2014. Evaluation of different vermicomposting sources as organic conditioners for conserving sandy soil under southern Kantara Shark, North Sinai. Egypt. J. of Appl. Sci. 29 (7b): 634-647.

Awad, E.M., 2002. Effect of compost and some bio-fertilizers on growth, yield and quality of potato crops (Solanum tubersum, L.). J. Agric. Sci, Mansoura, Univ., 27(8): 5525-5537.

Barral, M.T., R. Paradelo, A.B. Moldes, M. Dominguez and F. Diaz-Fierros, 2009. Utilization of MSW compost for organic matter conservation in agricultural soils of NW Spain. Resources conservation and recycling (53): 529-534.

Bernal, M.P., J.A. Alburquerque and R. Moral, 2009. Composting of animal manures and chemical criteria for compost maturity assessment. A review. Bioresource Tech. (100): 5444-5453.

Candemir, F., and C. Gülser, 2011. Effects of different agricultural wastes on some soil quality indexes in clay and loamy sand fields. Communications in Soil Sci. and Plant Analysis 42 (1):13-28.

Celik, I., I. Ortas and S. Kilic, 2004. Effects of compost, mycorrhiza, manure and fertilizer on some physical properties of a Chromoxerert soil. Soil and Tillage Rese. (78): 59-67.

Cercioglu, M., B. Okur, S. Delibacak and A. R. Ongun, 2012. Effects of tobacco waste and farmyard manure on soil properties and yield of lettuce (Lactuca sativa L. var. capitata). Communications in Soil Sci. and Plant Analysis (43):875-886.

De Bertoldi, M., G. Vallini and A. Pera, 1983. The biology of composting: a Review. Waste Management \& Research, (1):157-176.

EL-Etr, W.T., L.K.M. Ali and E.L. EL-Khatib, 2004. Comparative effects of bio-compost and compost on growth, yield and nutrients content of pea and wheat plants grown on sandy soils. Egypt. J. of Agric. Res., 82(2): 73-94.

El-Maaz, E.I.M., H.M.R.M. Ahmed and Kh. A. Shaban, 2014. Soil chemical properties and wheat productivity as affected by organic, bio-fertilization and cultivation methods in saline soil. Minufiya, J. Agric. Res., 39 (6): 1955-1968.

Farrell, M. and D.L. Jones, 2009. Critical evaluation of municipal solid waste composting and potential compost markets. Bioresource Tech. (100): 4301-4310.

Gao, M., F. Liang, A. Yu, B. Li and L. Yang, 2010. Evaluation of stability and maturity during forced- aeration composting of chicken manure and sawdust at different $\mathrm{C} / \mathrm{N}$ ratio. Chemosphere (78): 614-619.

Gilley, J.E. and L.M. Risse, 2000. Runoff and soil loss as affected by the application of manure. Trans. Am. Soc. Agric. Engin. (43):1583-1588.

Hepperly, P., D. Lotter, C.Z. Ulsh, R. Seidel and C. Reider, 2009. Compost, manure and Synthetic fertilizer influences crop yields, soil properties, nitrate leaching and crop nutrient content. Compost Science \& Utilization 17(2): 117-126

Jackson, M.L., 1973. Soil Chemical Analysis. Prentice Hall of Indian Private limited. New Delhi, India.

Johnson, G. A., J.G. Davis; Y.L. Qian and K.C. Doesken, 2006. Topdressing Turf with Composted Manure Improves Soil Quality and Protects Water Quality. Soil Sci. Soc. of America J., (70): 2114-2121. 
Kawasaki, S., N. Maie, S. Kitamura and A. Watanabe, 2008. Effect of organic amendment on amount and chemical characteristics of humic acids in upland field soils. Euro. J. of Soil Sci. (59): 1027-1037.

Klute, A., 1986. Methods of Soil Analysis : Part 1: Physical and Mineralogical Methods. (2 ${ }^{\text {nd }}$ Ed), Amer. Soc. Agron. Monograph No. 9, Madison, Wisconsin. U.S.A.

Larney, F.J., A.F. Olson, J.J. Miller, P.R. DeMaere, F. Zvomuya and T.A. McAllister, 2008. Physical and chemical changes during composting of wood chip-bedded and straw-bedded beef cattle feedlot manure. J. of Enviro. Quality, (37): 725-735.

Mylavarapu, R.S. and G.M. Zinati, 2009. Improvement of soil properties using compost for optimum parsley production in sandy soils. Scientia Horticulturae (120): 426-430.

Odlare, M. and M. Pell, 2009. Effect of wood fly ash and compost on nitrification and denitrification in agricultural soil. Applied Energy. (86): 74-80

Omran, A.M., A.M Falatah and A.R. Al-Harbi, 2002. The use of natural deposits as an alternative for polymers on water management in arid calcareous sandy soils of Saudi Arabia. $17^{\text {th }}$ World Congress of Soil Science, 14-21 August, Thailand.

Pattanayak, S.K., K.N. Mishra, M.K. Jena and R.K. Nayak, 2001. Evaluation of green manure crops fertilized with various phosphorus sources and their effect on subsequent rice crop. J. Indian Soc. Soil Sci., 49(2): 285-291.

Rashad, F.M., H.H. Kesba, W.D. Saleh and M.A. Moselhy, 2011. Impact of rice straw composts on microbial population, plant growth, nutrient uptake and root-knot nematode under greenhouse conditions. African J.of Agric. Res., 6 (5): 1188-1203.

Tan, K.H., 2003. Humic matter in soil and environment, principles and controversies. New York, USA, pp 154-278.

Tejada, M., M.T. Hernandez and C. Garcia, 2009. Soil restoration using composted plant residues: Effects on soil properties. Soil and Tillage Res. (102): 109-117.

Turner, B.L., E. Frossard and D.S. Baldwin, 2005. Organic phosphorus in the environment. Cambridge, MA, CABI, Publishing. pp. 366-369.

Wandruszka, R.V., 2006. Phosphorus retention in calcareous soils and the effect of organic matter on its mobility. Geochemical Transactions, 7(6): 1-8.

Weber, J., M. Licznar and J. Drozd, 2002. Changes in physical and physicochemical properties of sandy soil amended with composted municipal solid wastes. Innovative soil-plant systems for sustainable agricultural practices, OECD Izmir, Turkey. PP. 227-242.

Zaka, M.A., F. Mujeeb, G. Sarwar, N.M. Hassan and G. Hassan, 2003. Agromelioration of saline sodic soil. J. of Bio. Sci. 3(3): 329-334 